\title{
Retrospective radiographic and clinical analysis of implant survival placed after alveolar ridge preservation
}

\author{
Sung-Jo Lee ${ }^{1 \dagger}$, Hyun Jang ${ }^{1 \dagger}$, Hyun-Seung Shin ${ }^{1 *}$, Jung-Chul Park ${ }^{1}$ Young-Gyun Song ${ }^{2}$, In-Woo Cho ${ }^{1}$ \\ 'Department of Periodontology, College of Dentistry, Dankook University, Cheonan, Republic of Korea \\ 'Department of Prosthodontics, College of Dentistry, Dankook University, Cheonan, Republic of Korea
}

Purpose: The purpose of present study was to retrospectively analyze the survival rate of implant placed after alveolar ridge preservation by initial stability and radiographic measurements. Materials and Methods: In total, 19 patients who received 21 sandblasted, large-grit, acid-etched (SLA) implants were enrolled in this retrospective study. Implants placed after alveolar ridge preservation technique (ARP) 2 - 3 months healing period, Periotest value (PTV) measured at implant placement and before placed prosthodontics. Marginal bone level (MBL) was measured at implant placement and final recall check. Results: Overall survival rate of implant was $100 \%$. Mean PTV at implant placement was $-0.06 \pm 8.33$ and mean PTV before placed prosthodontics was $-5.75 \pm$ 1.72. The range of MBL change was from $-0.55 \mathrm{~mm}$ to $1.6 \mathrm{~mm}$ (Mean: $0.19 \pm 0.58 \mathrm{~mm}$ ). Conclusion: The findings of present study suggest that the implant paced after alveolar ridge preservation appear high survival rates and stable MBL. (J Dent Rehabil Appl Sci 2018;34(3):167-74)

Key words: alveolar process; alveolar ridge augmentation; dental implants; osseointegration; survival rate

\begin{abstract}
서론
발치 후 치조골의 형태는 시간이 지남에 따라 그 형태 와 폭이 변화하게 되는데 Schropp 등 ${ }^{1}$ 은 발치와의 변화 를 12 개월간의 임상적, 방사선학적 분석 결과 수평적으 로 평균 $5-7 \mathrm{~mm}$ 의 골 소실을 보이고 이는 발치 전 치조 골 폭의 약 $50 \%$ 의 감소라 보고하였고 Ten Heggeler 등 ${ }^{2}$ 은 체계적 고찰 논문에서 발치 후 치조골의 변화는 수평 적으로 $2.6-4.6 \mathrm{~mm}$, 수직적으로 $0.4-3.9 \mathrm{~mm}$ 의 흡수를 보인다 보고하였다. 이러한 치조골의 3차원적 변화는 임 플란트를 이상적인 위치에 식립하기 어려워져 심미적, 기 능적 요구를 만족시키기 어려워져 종종 골유도재생술, 상악동 거상술 등의 추가적인 술식을 필요로 하게 된다.
\end{abstract}

*Correspondence to: Hyun-Seung Shin

Assistant Professor, Department of Periodontology, Dankook University College of Dentistry, 119, Dandae-ro, Dongnam-gu, Cheonan, 31116, Republic of Korea Tel: +82-41-550-0263, Fax: +82-303-3442-7364, E-mail: perioshin@dankook.ac.kr Received: April 30, 2018/Last Revision: May 31, 2018/Accepted: July 16, 2018

† These authors equally contributed to this work as first authors.
그러나 추가적인 술식은 환자의 불편감, 치료기간 및 합 병증 발생 가능성 증가 등의 부작용을 동반할 수 있다. ${ }^{3}$

따라서 발치와의 흡수를 줄이는 방법으로 치조제 보 존술(Alveolar ridge preservation technique: ARP)이 소 개되었는데, 이는 발치 후 즉시 이식재를 적용하고 차폐 막 또는 연조직 피개 등을 이용하여 처치하는 방법으로 다수의 체계적 고찰과 메타분석 논문에서 ARP는 발치 후 치조제의 수직, 수평적 흡수를 유의하게 줄여준다 보 고되었다. ${ }^{2,4-6}$ 이식재의 경우 탈 단백 우골(Deproteinized bovine bone: DBBM)이 가장 많이 사용되는 것으로 보 고된 바 있으나 ${ }^{7}$ 어떠한 술식 및 재료가 우월한 결과를 나타내는지에 대한 표준이 되는 명확한 가이드라인은 부 족한 실정이다. ${ }^{8}$

Copyright@ 2018 The Korean Academy of Stomatognathic Function and Occlusion. (c) It is identical to Creative Commons Non-Commercial License. 
또한 ARP 후 치조제의 수직, 수평적 변화와 관련한 많 은 보고가 있는데 반해 ARP 시행 후 식립된 임플란트의 생존율에 관한 보고는 아직 이루어지지 않는 실정이다. 이식재를 적용시킨 부위에 식립된 임플란트 생존율을 추 정해보기 위해 골유도재생술을 시행한 부위에 식립된 임 플란트의 생존율에 관한 연구를 살펴보았을 때, 골유도 재생술을 시행하지 않은 부위에 식립된 임플란트의 생존 율과 비교한 장기간의 생존율에서 유의한 차이를 나타내 지 않았다 보고되었다. ${ }^{9,10}$

임플란트의 생존을 예측하기 위해 초기고정을 측정하 는 방법 중 Periotest ${ }^{\circledR}$ 는 전자식으로 제어되는 metal rod 가 치아 또는 임플란트와 접촉 후 돌아오는 시간을 계산 하여 Periotest value (PTV)라는 수치로 변환시켜주는데 -8 부터 50까지의 수치를 나타내게 된다. 낮은 수치를 나 타낼수록 고정력이 높은 것을 의미하며 Chavez 등 ${ }^{11}$ 은 in vivo 실험에서 임상적으로 동요도 없이 성공적인 임플란 트의 PTV값은 -6 에서 +2 를 나타내었고 in vitro 실험에 서 PTV값은 동요도가 증가됨에 따라 양의 선형관계를 나타내었다 보고하였으며, Olivé와 Aparicio ${ }^{12}$ 는 임상실 험을 통해 PTV값은 정량적이고 재현성 있어 쉽게 성공 적인 골 유착 여부를 평가할 수 있다고 보고하였다.

따라서 본 연구에서는 단국대학교 치과대학 부속 치과 병원 치주과에서 $\mathrm{ARP}$ 를 시행한 부위에 식립된 단일 종 류 임플란트의 일정기간 생존율을 PTV값과 방사선학적 계측을 통해 후향적으로 분석해 보았다.

\section{연구 재료 및 방법}

\section{1. 연구대상}

이번 연구는 2016년 4월부터 10월까지 단국대학교 치과 병원 치주과에서 sandblasted, large-grit, acid-etched (SLA) 표면을 갖는 단일 제품의 임플란트(IS II active ${ }^{\circledR}$, Neo biotech, Seoul, Korea)를 ARP 시행한 부위에 식립한 환자 를 대상으로 진행하였다(Approval No. H-1412/012/ 002). 임신 또는 수유, 암치료를 위한 5년 이내의 방사선 혹은 화학요법, 자가면역 질환, 교원질에 대한 이상 과민 증, 관혈적 수술이 금기시 되는 전신질환, 장기간의 비스 테로이드 항염증약 복용, 예방적 항생제 필요, 하루 10 개 피 이상의 흡연, 인접치의 치료되지 않은 치주염을 갖는 환자들은 대상에서 제외하였으며, 위 조건에 부합되는 환 자들 중 술 후 5 개월 -24 개월(평균 $15 \pm 4.97$ 개월) 간의
정기적 내원을 한 19 명의 환자에 식립된 21개의 임플란트 를 조사하였다. 환자의 나이 분포는 19 - 79세(평균 55.5 \pm 8.75 세)로 남성 9 명, 여성 10 명의 비율로 구성되었다.

\section{2. 연구방법}

2016년 1월부터 7월 사이에 ARP를 시행 받은 환자들 을 대상으로 임플란트를 식립하였다. ARP술식을 요약 하자면, 국소마취 하에 치조골에 손상을 최소화 하도록, 판막이 거상되지 않게 조심스럽게 발치 후 내부의 육아 조직 및 염증성 조직들을 외과용 소파기(surgical curette) 로 제거해준다. 정리된 발치와를 생리식염수로 세척 후 교원질이 10\% 포함된 DBBM-C (Bio-Oss ${ }^{\circledR}$ Collagen, Geistlich Pharma, Wolhusen, Switzerland)을 적용해 주고, 흡수성 교원질 차폐막 $\left(13 \times 25 \mathrm{~mm}\right.$, Bio-Gide ${ }^{\circledR}$, Geistlich Pharma, Wolhusen, Switzerland)을 반으로 잘 라 각각 발치와 형태에 맞게 조정 후 두 겹의 차폐막으 로 발치와를 피개(Double layer coverage)해 주었다. 피 개된 차폐막은 Hidden X suture를 통해 고정시켜주었 으며 ${ }^{13} 2$ - 3개월의 치유기간 이후 임플란트를 식립하였 고, Periotest ${ }^{\circledR} \mathrm{M}$ (Periotest ${ }^{\circledR} \mathrm{M}$, Medizintechnik Gulden e.K., Modautal, Germany)으로 식립 시의 PTV값 및 보 철 시행 전 PTV값을 측정하였다. 발치 원인, 식립 위치, $\mathrm{ARP}$ 후 임플란트 식립 시기의 기간, 점검 시의 기간을 조 사하였으며 디지털 파노라마 방사선 사진을 통해 식립된 임플란트의 근 원심 Marginal bone level (MBL)을 방사 선 계측 프로그램(PACSPLUS viewer, Medical Standard Co., Ltd., Seoul, Korea)을 이용하여 측정하였다. 최종 $\mathrm{MBL}$ 의 측정은 가장 마지막 점검 내원 시 촬영한 파노라 마 방사선 사진을 통해 계측하였다. 임플란트 생존율은 Buser 등이 제시한 기준을 따라 평가하였다. 1) 단일 임 플란트에 압력을 주었을 때 동요도가 없어야 하며, 2) 방 사선 사진 상 임플란트 주위에 연속적인 방사선 투과상 이 없고, 3) 통증 또는 감염 등의 지속적이고 비 가역적인 증상 및 징후가 없어야 할 것이다. ${ }^{14-16}$

\section{결과}

발치 원인은 치주병소 11 개, 근관병소 3 개, 근관-치 주병소 4 개, 치근 우식 2 개, 치근 파절 1 개 였고 상악 10 개, 하악 11 개가 식립 되었으며 대구치 19개, 견치1개, 전 치 1 개였다. ARP 시행 후 임플란트 식립까지 평균 3.62 
\pm 0.59 개월이었고 식립 후 보철 시행 전 점검까지 평균 $3.40 \pm 1.16$ 개월이었다. 임플란트 식립 시 PTV값은 -7.2 에서 32.5 의 범위로 평균 $-0.06 \pm 8.33$ 이며 보철 시행 전 점검 시 PTV값은 -7.9에서 -1.6의 범위로 평균 $-5.75 \pm$ 1.72 이었다. 임플란트 식립 후 최소 5 개월에서 최대 24 개 월(평균 15 개월) 시점에서 임플란트의 생존율은 $100 \%$ 로
나타났으며 MBL의 변화는 근심 $-1.6 \mathrm{~mm}$ 에서 $2.1 \mathrm{~mm}$ 의 범위로 평균 $0.21 \pm 0.75 \mathrm{~mm}$, 원심 $-1.1 \mathrm{~mm}$ 에서 $1.2 \mathrm{~mm}$ 의 범위로 평균 $0.18 \pm 0.53 \mathrm{~mm}$ 를 나타내었다. 근 원심 평균 MBL의 변화는 $-0.55 \mathrm{~mm}$ 에서 $1.6 \mathrm{~mm}$ 의 범위로 평 균 $0.19 \pm 0.58 \mathrm{~mm}$ 를 나타내었다(Fig. 1 - 3).

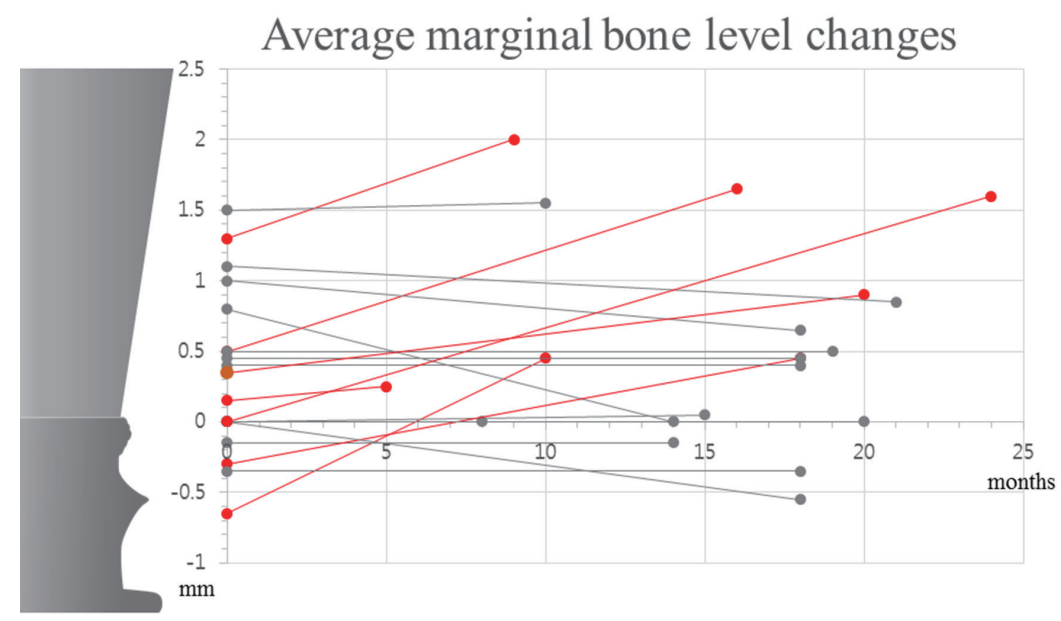

Fig. 1. Diagrams illustrating the average of mesial-distal marginal bone level of all implants. The marginal bone level was measured at fixture insertion (0 month), and at final recall (final months). Red lines mean increasing of marginal bone levels.
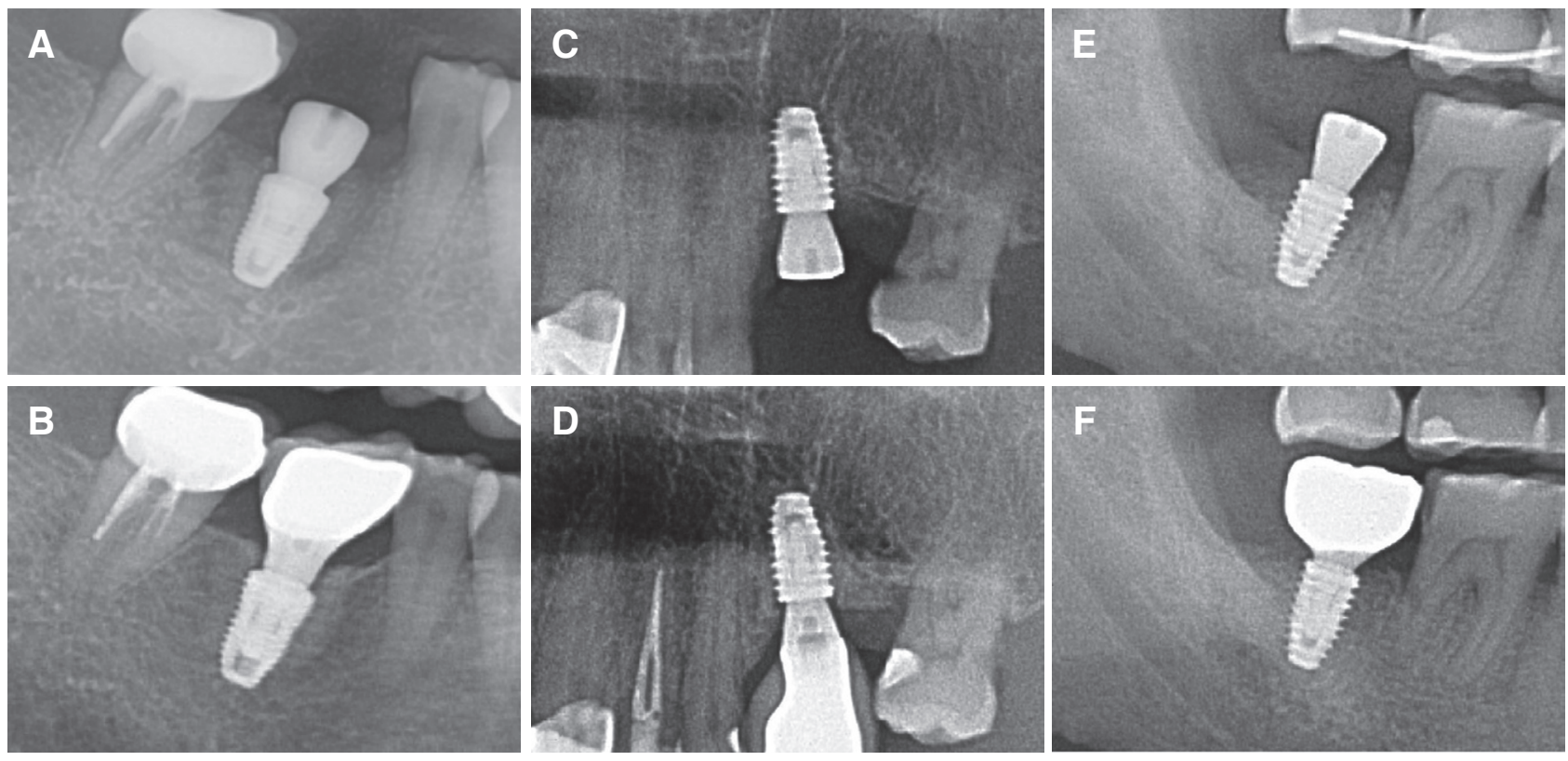

Fig. 2. Radiographic evaluation of marginal bone level change of implants which placed in ARP site (Increased MBL after loading). (A) Radiographic image of case 1 (After implant placement), (B) Final recall check of case 1 (21 months later), (C) Radiographic image of case 2 (After implant placement), (D) Final recall check of case 2 (14 months later), (E) Radiographic image of case 3 (After implant placement), (F) Final recall check of case 3 (21 months later).

The images cropped from panoramic view. 

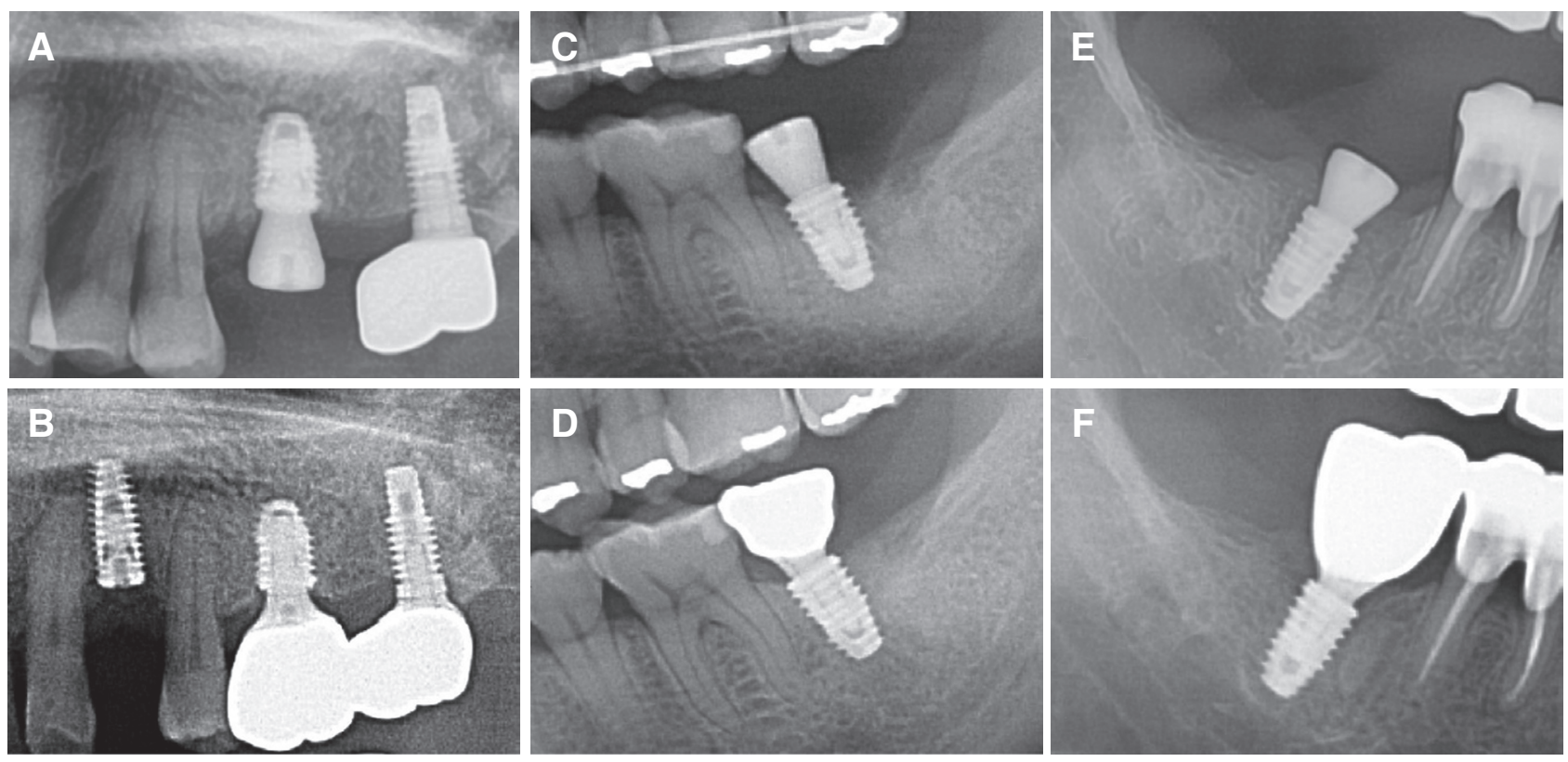

Fig. 3. Radiographic evaluation of marginal bone level change of implants which placed in ARP site (Decreased or same MBL after loading). (A) Radiographic image of case 4 (After implant placement), (B) Final recall check of case 4 (24 months later), (C) Radiographic image of case 5 (After implant placement), (D) Final recall check of case 5 (18 months later), (E) Radiographic image of case 6 (After implant placement), (F) Final recall check of case 6 (16 months later).

The images cropped from panoramic view.

\section{고찰}

발치와의 흡수를 줄여 보기 위한 방법으로 발치 후 즉 시 임플란트 식립을 통해 치조골의 변화를 줄이려는 노 력이 있었는데 동물 연구 실험을 통해 이는 불가능하 다 결론지었고, ${ }^{17,18}$ 이에 따라 주목받게 된 $\mathrm{ARP}$ 는 자가 골(Autobone), 탈회동결건조골(Demineralized freezedried bone allograft), ${ }^{19}$ 생활성 유리(Bioactive glass), ${ }^{20}$ 합 성 중합체(alloplastic poylmers), ${ }^{21} \mathrm{DBBM}$ 등 $^{22}$ 의 다양한 재료들을 통한 연구가 진행되어왔다. 이들 중 $\mathrm{DBBM}$ 을 이용한 연구에서 Artzi 등 ${ }^{23}$ 은 발치와 내 $\mathrm{DBBM}$ 을 적용 후 9개월 뒤 조직학적 분석을 시행한 결과 흡수되지 않은 이식재들이 관찰되었고 발치와 내부 $82.3 \%$ 의 신생골 형 성을 확인하였다 보고하였다. 해당 연구에서는 장기간의 추가적인 연구를 통해 흡수되지 않은 이식재들의 변화양 상을 더 관찰해야 할 것으로 결론지었으나, $\mathrm{ARP}$ 의 주된 목적인 발치와의 발치 전 상태를 유지하기 위해 이식재가 흡수되지 않는 것은 공간유지능력 측면에서 매우 유리할 것으로 사료된다. 또한 신생골의 적절한 형성이 확인되었 고 이는 골유도능이 충분한 것으로 사료되어 본 연구에 서는 DBBM을 이식재료로 사용하게 되었다.
$\mathrm{ARP}$ 의 시행에 있어 발치와 상부 연조직의 피개를 이 루는 방법은 발치 후 즉시 임플란트 식립 시 연조직의 완 전한 피개가 어려울 경우 사용하던 술식들을 이용해왔 다. Becker 등 ${ }^{24}$ 은 협측 판막을 치관측으로 재위치 시키 는 방법으로 발치와의 피개를 이루는 방법을 소개하였고 Rosenquist $^{25}$ 는 협측 유경판막을 형성하여 이를 회전시켜 피개하는 방법을 소개하였다. Jung 등 ${ }^{26}$ 은 $2-3 \mathrm{~mm}$ 두께 의 구개측 유리 치은을 펀치로 채득하여 발치와 상부를 피개하는 방법을 소개하였다. 그러나 이러한 방법들은 인접 연조직의 추가적인 처치가 필요하며, 이는 환자의 불편감 증가를 유발할 수 있다.

따라서 본 연구에서는 덜 침습적인 방법으로 흡수성 차폐막을 이용해 발치와를 피개하는 방법을 선택하였 는데, Cardaropoli 등 ${ }^{27}$ 은 발치와 내에 이식재를 적용 후 상부에 일차봉합(primary closure)을 이루지 않고 흡수 성 차폐막을 적용하여 $\mathrm{ARP}$ 를 시행한 후 4개월 뒤 임상 적, 조직학적으로 분석 했을 때 성공적으로 치조제 흡수 를 줄일 수 있었고 임플란트 식립에 적합한 신생골 형성 을 관찰할 수 있다 보고하였다. 또한 Engler-Hamm 등 ${ }^{28}$ 은 ARP 시행 시 흡수성 차폐막을 적용 후 일차봉합을 이 루지 않은 경우가 더 많은 각화 치은을 보존하게 되고 치 
조제 폭경의 소실이 더 적었다 보고한 바 있다. Choi 등 ${ }^{29}$ 은 두 겹의 차폐막을 통한 피개(double layer coverage)를 통한 ARP 시행 시 골 흡수 량 측면에서 한 겹의 차폐막 을 통한 피개에 비해 통계적으로 유의한 우월한 결과를 나타내지는 않았으나, 구강내 노출된 외부 차폐막의 빠 른 분해를 내부 차폐막이 상충해 줄 수 있고 치유 능력이 떨어져 발치와의 연조직 치유가 느린 환자에 있어 잠재적 으로 유리할 것으로 사료된다 보고하였다. 이 결과를 토 대로 본 연구에서는 두 장의 차폐막을 통해 발치와를 일 차봉합 없이 피개하기로 결정하였다.

차폐막의 위치를 유지시키기 위해 발치와를 봉합하는 방법으로 기존의 많은 ARP 연구들에서 대부분 crossed mattress suture ${ }^{30}$ 또는 cross suture ${ }^{31}$ 를 시행하였으나 본 연구에서는 Hidden X suture를 시행하였다. Park 등 ${ }^{13}$ 은 기존의 연구에서 사용된 봉합들은 협측 각화 치은 폭 경을 줄어들게 만들고 치은치조점막경계(Mucogingival junction)를 설측으로 이동시킨다는 단점이 존재한다 설 명하며 Hidden X suture를 소개하였다. 기존의 봉합들은 협 설측 방향의 벡터가 발생하나, Hidden X suture의 경 우 근 원심 방향의 벡터가 발생되어 협측 치은이 설측으 로 당겨지지 않으면서 차폐막의 위치를 유지시켜줄 수 있 고 결과적으로 치은치조점막경계의 위치변화와 각화 치 은양의 변화가 유의하게 줄어들었다 보고하였다.

$\mathrm{MBL}$ 계측 시 전체 임플란트 중 6케이스에서 근 원심 모두 양의 값을 나타내었고 근심 또는 원심에서 양의 값 을 나타낸 케이스가 각각 1 개씩 있어 식립 직후보다 증 가된 MBL 값을 나타내었다(Fig. 2). 또한 방사선 사진상 임플란트 주위 골이 더 광화되어 보이는 방사선 불투과 상을 확인하였다(Fig. 2, 3). 이러한 경향은 ARP 시 이식 된 골이 일정 수준의 골유도능을 가져 시간이 지남에 따 라 신생골의 형성이 계속적으로 지속된 것으로 추정된다. $\mathrm{MBL}$ 이 증가된 양상 또한 신생골이 임플란트 표면을 자 라 올라갔다고 해석하기보다는 방사선 투과상을 나타낼 정도의 낮은 신생골 밀도를 나타내던 이식 부위의 신생 골 밀도가 증가되며 보다 명확한 방사선 불투과상을 나 타내었다 해석할 수 있다 사료된다. 향후 이러한 결과에 대해 조직학적 소견을 포함한 추가적인 연구가 필요할 것이다.

본 연구에서는 디지털 파노라마 사진을 이용한 계측을 시행하였는데, Vazquez 등 ${ }^{32}$ 은 임플란트와 금속 공을 이 용한 디지털 파노라마의 정밀도에 대한 연구에서 임플란 트의 방사선 사진 상 수직적 변형율은 $0.9 \%$ 로 이는 0.1 $\mathrm{mm}$ 의 오차이며 실제 임플란트 길이와 통계적으로 유의 한 차이는 없었다고 보고하였다. 본 연구에서는 디지털 파노라마 방사선 사진을 이용하여 $\mathrm{MBL}$ 을 측정하였기 에 정밀도와 재연성을 얻기 용이하였으나 이차원적 사진 이라는 한계점이 있다. 추후 진행될 연구에서는 CBCT를 이용한 삼차원적 계측 및 보다 선예도 높은 정밀한 측정 이 필요로 할 것으로 사료된다. 또한 표본수가 적고 관찰 기간이 짧아 장기간의 성공적인 예후 등의 결과를 예지 성 있게 신뢰하기는 부족했다. 이에 연구의 신뢰도를 높 이기 위해 더 많은 표본 수를 통한 장기간의 연구 결과가 필요할 것으로 사료된다.

\section{결론}

이번 연구를 통해 다음과 같은 결론을 내렸다.

1. 발치와를 두 겹의 차폐막으로 피개하고 Hidden X suture를 시행한 ARP에 식립된 임플란트는 높은 생 존율을 나타낸다 $(100 \%)$.

2. ARP 시행 후 식립된 임플란트의 $\mathrm{MBL}$ 은 평균적으 로 증가된 수치를 나타낸다.

3. $\mathrm{DBBM}$ 을 통해 ARP를 시행한 부위는 지속적인 신 생골 형성에 따른 방사선학적 광화가 관찰된다.

비록 한계점이 있는 연구이나, 위의 결과로 미루어 보 아 ARP를 시행 한 부위는 임플란트 식립에 적절한 새로 운 골을 형성하여 식립된 임플란트의 적절한 초기고정 및 생존율을 나타내며 안정적인 변연골 유지를 보이는 것으 로 사료된다.

\section{Acknowledgements}

This present research was conducted by the research fund of Dankook University in 2016 (R-2016-00430).

\section{ORCID}

Sung-Jo Lee https://orcid.org/0000-0002-7834-209X Hyun Jang https://orcid.org/0000-0002-7484-4623 Hyun-Seung Shin https://orcid.org/0000-0002-1410-9731 Jung-Chul Park https://orcid.org/0000-0002-2041-8047 Young-Gyun Song https://orcid.org/0000-0003-37899585

In-Woo Cho https://orcid.org/0000-0003-4985-3816 


\section{References}

1. Schropp L, Wenzel A, Kostopoulos L, Karring $\mathrm{T}$. Bone healing and soft tissue contour changes following single-tooth extraction: a clinical and radiographic 12-month prospective study. Int J Periodontics Restorative Dent 2003;23:313-23.

2. Ten Heggeler JM, Slot DE, Van der Weijden GA. Effect of socket preservation therapies following tooth extraction in non-molar regions in humans: a systematic review. Clin Oral Implants Res 2011;22:779-88.

3. Chiapasco M, Zaniboni M. Clinical outcomes of GBR procedures to correct peri-implant dehiscences and fenestrations: a systematic review. Clin Oral Implants Res 2009;20 Suppl 4:113-23.

4. Vignoletti F, Matesanz P, Rodrigo D, Figuero E, Martin C, Sanz M. Surgical protocols for ridge preservation after tooth extraction. A systematic review. Clin Oral Implants Res 2012;23 Suppl 5:2238.

5. Avila-Ortiz G, Elangovan S, Kramer KW, Blanchette D, Dawson DV. Effect of alveolar ridge preservation after tooth extraction: a systematic review and meta-analysis. J Dent Res 2014;93:950-8.

6. MacBeth N, Trullenque-Eriksson A, Donos N, Mardas N. Hard and soft tissue changes following alveolar ridge preservation: a systematic review. Clin Oral Implants Res 2017;28:982-1004.

7. Araújo MG, Silva CO, Misawa M, Sukekava F. Alveolar socket healing: what can we learn? Periodontol 2000 2015;68:122-34.

8. Mardas N, Trullenque-Eriksson A, MacBeth N, Petrie A, Donos N. Does ridge preservation following tooth extraction improve implant treatment outcomes: a systematic review: Group 4: Therapeutic concepts \& methods. Clin Oral Implants Res 2015;26 Suppl 11:180-201.

9. Corrente G, Abundo R, Cardaropoli D, Cardaropoli G, Martuscelli G. Long-term evaluation of osseointegrated implants in regenerated and nonregenerated bone. Int J Periodontics Restorative Dent 2000;20:390-7.

10. Nevins M, Mellonig JT, Clem DS 3rd, Reiser GM, Buser DA. Implants in regenerated bone: long- term survival. Int J Periodontics Restorative Dent 1998;18:34-45.

11. Chavez H, Ortman LF, DeFranco RL, Medige J. Assessment of oral implant mobility. J Prosthet Dent 1993;70:421-6.

12. Olivé J, Aparicio C. Periotest method as a measure of osseointegrated oral implant stability. Int J Oral Maxillofac Implants 1990;5:390-400.

13. Park JC, Koo KT, Lim HC. The hidden X suture: a technical note on a novel suture technique for alveolar ridge preservation. J Periodontal Implant Sci 2016;46:415-25.

14. Buser D, Weber HP, Lang NP. Tissue integration of non-submerged implants. 1-year results of a prospective study with 100 ITI hollow-cylinder and hollow-screw implants. Clin Oral Implants Res 1990;1:33-40.

15. Buser D, Mericske-Stern R, Bernard JP, Behneke A, Behneke N, Hirt HP, Belser UC, Lang NP. Longterm evaluation of non-submerged ITI implants. Part 1: 8-year life table analysis of a prospective multi-center study with 2359 implants. Clin Oral Implants Res 1997;8:161-72.

16. Buser D, Mericske-Stern R, Dula K, Lang NP. Clinical experience with one-stage, non-submerged dental implants. Adv Dent Res 1999;13:153-61.

17. Araújo MG, Sukekava F, Wennström JL, Lindhe J. Ridge alterations following implant placement in fresh extraction sockets: an experimental study in the dog. J Clin Periodontol 2005;32:645-52.

18. Blanco J, Liñares A, Pérez J, Muñoz F. Ridge alterations following flapless immediate implant placement with or without immediate loading. Part II: a histometric study in the Beagle dog. J Clin Periodontol 2011;38:762-70.

19. Becker W, Becker BE, Caffesse R. A comparison of demineralized freeze-dried bone and autologous bone to induce bone formation in human extraction sockets. J Periodontol 1994;65:1128-33.

20. Froum S, Cho SC, Rosenberg E, Rohrer M, Tarnow D. Histological comparison of healing extraction sockets implanted with bioactive glass or demineralized freeze-dried bone allograft: a pilot study. J Periodontol 2002;73:94-102.

21. Serino G, Biancu S, Iezzi G, Piattelli A. Ridge pres- 
ervation following tooth extraction using a polylactide and polyglycolide sponge as space filler: a clinical and histological study in humans. Clin Oral Implants Res 2003;14:651-8.

22. Nevins M, Camelo M, De Paoli S, Friedland B, Schenk RK, Parma-Benfenati S, Simion M, Tinti C, Wagenberg B. A study of the fate of the buccal wall of extraction sockets of teeth with prominent roots. Int J Periodontics Restorative Dent 2006;26: 19-29.

23. Artzi Z, Tal H, Dayan D. Porous bovine bone mineral in healing of human extraction sockets. Part 1: histomorphometric evaluations at 9 months. J Periodontol 2000;71:1015-23.

24. Becker W, Becker BE. Guided tissue regeneration for implants placed into extraction sockets and for implant dehiscences: surgical techniques and case report. Int J Periodontics Restorative Dent 1990;10: 376-91.

25. Rosenquist B. A comparison of various methods of soft tissue management following the immediate placement of implants into extraction sockets. Int J Oral Maxillofac Implants 1997;12:43-51.

26. Jung RE, Siegenthaler DW, Hammerle CH. Postextraction tissue management: a soft tissue punch technique. Int J Periodontics Restorative Dent 2004;24:545-53.

27. Cardaropoli D, Cardaropoli G. Preservation of the postextraction alveolar ridge: a clinical and histologic study. Int J Periodontics Restorative Dent
2008;28:469-77.

28. Engler-Hamm D, Cheung WS, Yen A, Stark PC, Griffin T. Ridge preservation using a composite bone graft and a bioabsorbable membrane with and without primary wound closure: a comparative clinical trial. J Periodontol 2011;82:377-87.

29. Choi HK, Cho HY, Lee SJ, Cho IW, Shin HS, Koo KT, Lim HC, Park JC. Alveolar ridge preservation with an open-healing approach using single-layer or double-layer coverage with collagen membranes. J Periodontal Implant Sci 2017;47:372-80.

30. Cardaropoli D, Tamagnone L, Roffredo A, Gaveglio L, Cardaropoli G. Socket preservation using bovine bone mineral and collagen membrane: a randomized controlled clinical trial with histologic analysis. Int J Periodontics Restorative Dent 2012; 32:421-30.

31. Jung RE, Sapata VM, Hammerle CHF, Wu H, Hu XL, Lin Y. Combined use of xenogeneic bone substitute material covered with a native bilayer collagen membrane for alveolar ridge preservation: A randomized controlled clinical trial. Clin Oral Implants Res 2018;29:522-9.

32. Vazquez L, Nizamaldin Y, Combescure C, Nedir R, Bischof M, Dohan Ehrenfest DM, Carrel JP, Belser UC. Accuracy of vertical height measurements on direct digital panoramic radiographs using posterior mandibular implants and metal balls as reference objects. Dentomaxillofac Radiol 2013;42:20110429. 


\section{발치와 치조제 보존술 시행 후 식립한 임플란트의 방사선학적 및 임상적 후향적 연구}

이성조 ${ }^{\dagger}$, 장현 $^{1 \dagger}$, 신현승 ${ }^{*}$, 박정철 ${ }^{1}$, 송영균 $^{2}$, 조인우 $^{1}$

${ }^{1}$ 단국대학교 치과대학 치주과학교실

${ }^{2}$ 단국대학교 치과대학 보철학교실

목적: 발치와에 치조제 보존술을 시행한 부위에 식립한 임플란트의 일정 기간의 생존율을 초기고정 값과 방사선학적 계 측을 통해 분석해보고자 하였다.

연구 재료 및 방법: 19명의 환자에 sandblasted, large-grit, acid-etched (SLA) 표면을 갖는 단일 제품의 21개의 임플란트 를 조사하였다. 임플란트는 치조제 보존술(Alveolar ridge preservation technique: ARP) 시행 후 2 - 3개월의 치유 기간 후 식립 되었으며, 식립 시 및 보철 시행 전 Periotest value (PTV)와 식립 시 및 최종 점검시의 방사선 사진을 통한 Marginal bone level (MBL)의 변화를 측정하였다.

결과: 전체 임플란트의 생존율은 $100 \%$ 로 나타났고 식립 시의 PTV는 평균 $-0.06 \pm 8.33$ 이었으며 보철 시행 전 PTV는 평 균 $-5.75 \pm 1.72$ 이었다. 근 원심 평균 MBL의 변화는 $-0.55 \mathrm{~mm}$ 에서 $1.6 \mathrm{~mm}$ 의 범위로 평균 $0.19 \pm 0.58 \mathrm{~mm}$ 를 나타내었다. 결론: 발치와 보존술을 시행한 부위에 식립한 임플란트는 높은 생존율을 나타내며 안정적인 변연골 유지를 보이는 것으 로 사료된다.

(구강회복응용과학지 2018;34(3):167-74)

주요어: 치조돌기; 치조제 증대술; 치과 임플란트; 골유착; 생존율

*교신저자: 신현승

(31116) 충남 천안시 동남구 단대로 119 단국대학교 치과대학 치주과학교실

Tel: 041-550-0263 || Fax: 303-3442-7364 || E-mail: perioshin@dankook.ac.kr

접수일: 2018년 4월 30일 | 수정일: 2018년 5월 31일 | 채택일: 2018년 7월 16일

$\dagger$ 위 저자들은 동일한 기여도를 갖는 저자입니다. 